\title{
Human Ocular Dirofilariasis- An Emerging Zoonotic Infection in India
}

\author{
Mahajan RK ${ }^{1}$, Sharma $\mathrm{S}^{1 *}$, Das $\mathrm{S}^{2}$, Neelmani ${ }^{1}$ and Malik $\mathrm{PK}^{3}$ \\ ${ }^{1}$ Department of Microbiology, Postgraduate Institute of Medical Education and Research (PGIMER) \& Ram Manohar Lohia Hospital, India \\ ${ }^{2}$ Department of Microbiology, University College of Medical Sciences (UCMS) \& Guru Teg Bahadur Hospital, India \\ ${ }^{3}$ Department of Opthalmology, Postgraduate Institute of Medical Education and Research (PGIMER) \& Ram Manohar Lohia Hospital, India
}

Submission: December 04, 2017; Published: December 12, 2017

*Corresponding author: Sharma S, Department of Microbiology, Postgraduate Institute of Medical Education and Research (PGIMER) \& Ram

Manohar Lohia Hospital, New Delhi, India, Email: drshwetamicro@gmail.com

\begin{abstract}
Dirofilaria is a filarial nematode that causes natural infection in mammals like dogs, felids, foxes, beavers etc. and humans are accidental hosts. We report here a case of Dirofilaria recovered from the subconjunctival tissue of the eye of a 55yrs old male patient, who presented with complaint of swelling in his right eye.
\end{abstract}

Keywords: Dirofilaria; Subconjunctival; Human

\section{Introduction}

Dirofilaria is a filarial nematode that causes natural infection in mammals like dogs, felids, foxes, beavers etc. Humans are accidental hosts and out of forty species of Dirofilaria identified, $D$. repens and $D$. immitis have been most commonly associated with human infections [1-3]. All Dirofilaria larvae are filariforms. The infecting larva is the filariform larva of third stage or L3. Culicid mosquitoes belonging to any of these genera; Anopheles, Culex, Aedes, Mansonia, Culiseta and Armigeres can act as the vector for the transmission of the infection. The L3 larvae penetrates the human tissue usually don't survive and those that manage to survive may develop into adult worms but they cannot fully develop in humans and do not produce microfilariae as a general rule [4]. There are exceptions to this rule in literature where adult worms in human tissue can also produce microfilaria [4-6].

D. immitis is a parasite that commonly infects cardiovascular system of canines and also has the potential to involve human pulmonary system. D.repens commonly localizes in the subcutaneous tissue of definitive host and in humans infection usually presents as solitary nodule but the worm may migrate in the subcutaneous tissue causing creeping eruptions and rarely may it infect other organs like lungs, female breast or eye. Ocular involvement may be orbital, periorbital, sub-conjunctival or intra-vitreal $[7,8]$.
We report here a case of Dirofilaria recovered from the subconjunctival tissue of the eye of a 55 years old male patient, who was presented with complaint of swelling in his right eye.

\section{Case Report}

A 55-year-old male reported to ophthalmology OPD in a tertiary care centre, New Delhi with complaint of pain and redness in the right eye since 5 days. On examination, a tender sub-conjunctival cystic swelling of $1 \mathrm{x} 1 \mathrm{~cm}$ was detected under the bulbar conjunctiva on the temporal side of the right eye with congestion. Visual acuity was $6 / 6$ in both the eyes and other ocular examination was within normal limits. There was no history of injury, allergy or any previous lesions in the eye.

The patient was non-hypertensive, non-diabetic with no other systemic illness. There was no history of travel to other places in the last two years. An examination of the patient's stool did not reveal any parasitic ova or cyst and peripheral blood smear did not show eosinophilia or microfilaria. A surgical procedure was undertaken to remove the cyst and during the procedure a live coiled worm was seen moving in the cyst which was gently extracted with a pair of forceps. The worm was referred to the Department of Microbiology in formal saline for establishing its identification. The worm was identified using morphological features published by Levine [9]. The worm was 
white, elongated, $0.5 \mathrm{~mm}$ thick and $11 \mathrm{~cm}$ in length while at the two ends it was comparatively thin (Figure 1). The cuticle was multilayered with distinct longitudinal ridging (Figure 2) and the anterior end of the worm was showing mouth and the esophagus tube with a vulval opening. Based on the size, cuticular and internal morphologic features, the worm was resembling adult female Dirofilaria (Nochtiella) repens. No further treatment was required after removal of worm (Figure 3).

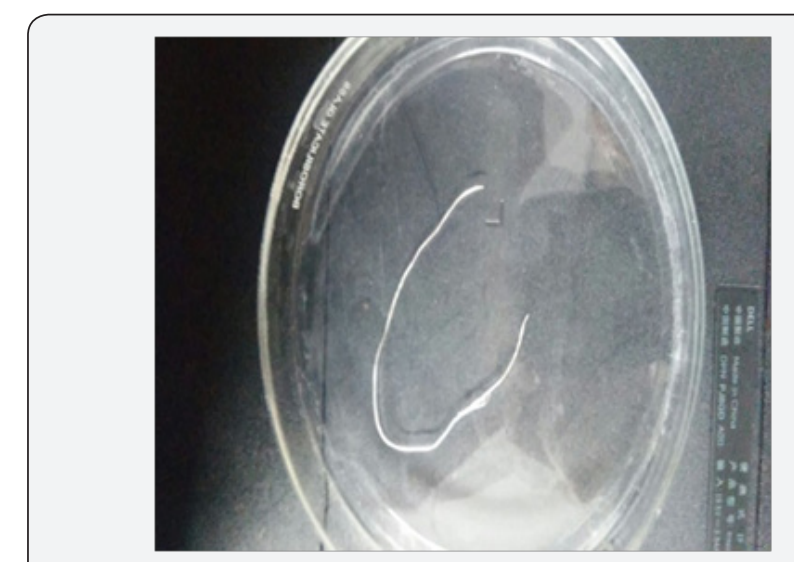

Figure 1: White worm $11 \mathrm{~cm}$ in length with tapering ends which was removed surgically.
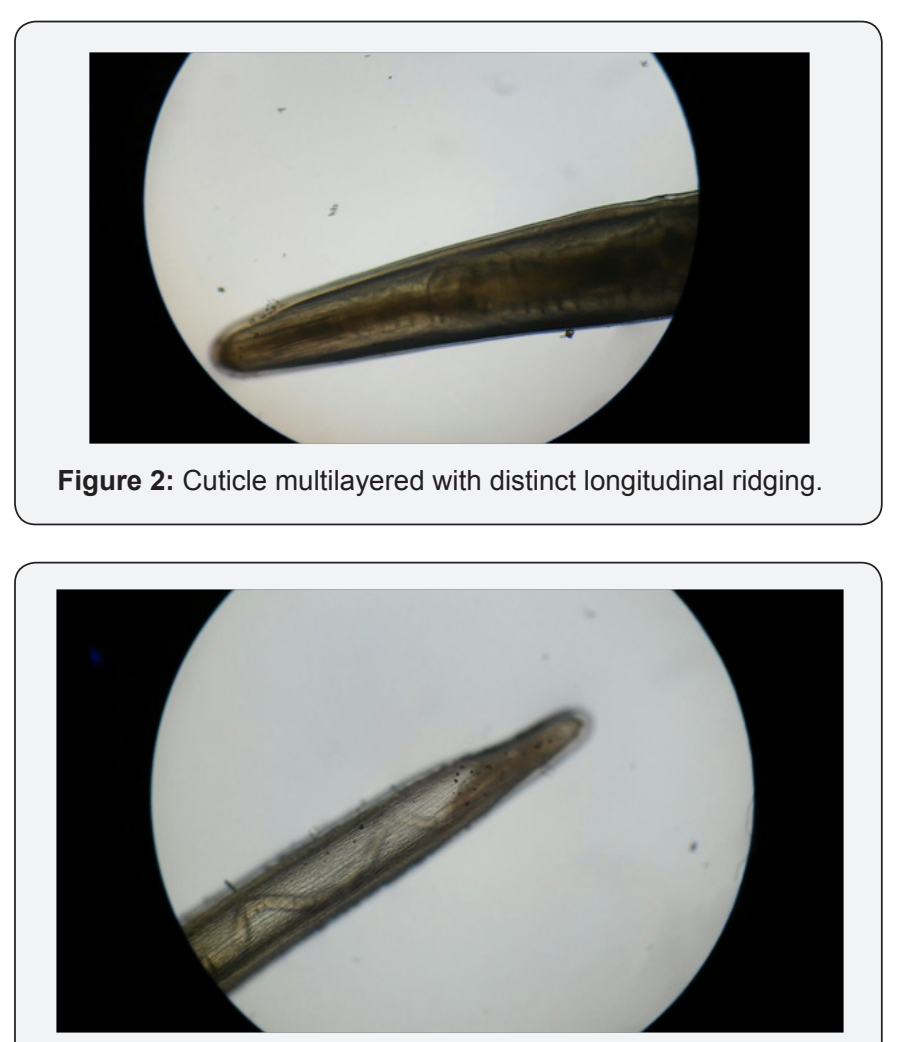

Figure 3: Anterior end of worm showing mouth and oesophagus.

\section{Discussion}

Dirofilariasis is a zoonotic infection that was once considered endemic to Mediterranean countries, is being reported from different corners of the world including Africa, Australia, America and Asia. Six of the forty reported species of the Dirofilaria; D. immitis, D. repens, D. striata, D. tenuis, D. ursi and D. spectans are known to cause disease in humans [1]. D. immitis is responsible for pulmonary Dirofilariasis, while D. repens has been associated with subcutaneous and ocular pathologies [10].

Since the publication of first report of $D$. repens by Angelo Pace in 1867 [11], there has been gradual increase in the number of cases, with majority of them reported in the last couple of decades itself. Pampiglione et al. [3] document reference of 782 cases caused by D. repens worldwide with 372 of them reported only from 1995-2000 [3]. With another fifteen years into this century, this figure is likely to have multiplied further.

In India, Dirofilariasis is considered endemic to Southern states of India and the first recorded report of human ocular Dirofilariasis is from Kerala in 1976 [12]. However cases have also been reported from northern and western regions of the country [13]. Patel et al. [14] in their brief communication of 2014, document reference of 19 cases of human Dirofilariasis from India as on 15th July 2011 [15]. This figure is expected to increase further with fresh reports. Most of the documented cases of human Dirofilariasis recorded in India had ocular infections, with few case reports showing subcutaneous Dirofilariasis $[12,13]$.

Clinical features of ocular Dirofilariasis depend upon the actual site of ocular area affected; skin of eyelid, conjunctiva, the tenon membrane, a retrobulbar space or intrabulbar structures. The site of localization of the parasite has direct bearing on the associated disability and complications. The most common localization is sub-conjunctiva or sub-tenon space and the diagnosis in both the situations is easier and more exact because the conjunctiva is transparent and possibility of direct detection of parasite is significant. In this particular case, the lesion was in the form of a cyst and a simple incision into the cyst made the worm wriggle out of the lesion. The worm was identified as $D$. repens on the basis of morphological features.

Direct examination of the parasite remains the mainstay of diagnosis because the robust serological systems are not available and eosinophilia that may be detectable in about $15 \%$ cases usually doesn't help steering the course of narrowing down the differential diagnosis [16]. Presently, no diagnostic system for early diagnosis of this infection is available and the necessity of this modality appears essential to avoid unnecessary investigative trauma on grounds of misdiagnosis of the condition as malignant tumour.

Removal of the parasite through surgical intervention or conventional extraction methods is the treatment of choice. Since there is no microfilariaemia, the antihelminths may have no therapeutic role and the use of antifilarial drugs is not evidenced in literature, though prophylactic use of DEC [Di Ethyl Carbamazine] or Ivermectin may be considered to destroy any 
worm that may be occupying some cryptic location and may not be producing any clinical trouble $[13,17]$. Moreover, human Dirofilaria infection with more than one worm is rare and infrequent.

\section{Conclusion}

Human Dirofilariasis could be an emerging zoonotic infection though there appears to be underreporting of cases on account of cases remaining undiagnosed or unpublished. With roaring population of dogs and cats combined with teeming numbers of mosquito vectors, this infection appears to have all the epidemiological instruments available to establish itself firmly in northern India and Dirofilariasis once considered endemic to southern India can make its pan India presence visible very emphatically. There is need to raise awareness among the medical scientists to the issues and challenges related to diagnosis and management of human Dirofilariasis. Also, preventive strategies like; chemoprophylaxis of animals and vector control, require to be put in place since the parasite involving cardiovascular system has the potential to cause significant morbidity.

\section{References}

1. Nath R, Gagoi R, Bardoloi N, Gogoi T (2010) Ocular Dirofilariasis Indian J Pathol Microbiol 53(1):157-159.

2. Orihel TC, Eberhard ML (1998) Zoonotic filariasis. Clin Microbiol Rev 11(2): 366-381.

3. Pampiglione S, Rivasi F, Angeli G, Boldorini R, Incensati RM, et al. (2001) Dirofilariasis due to Dirofilaria repens in Italy, an emergent zoonosis: report of 60 new cases. Histopathology 38(4): 344-354.

4. Sulekova LF, Gabrielli S, De Angelis M, Milardi GL, Magnani C, et al. (2016) Dirofilaria repens microfilariae from a human node fine-needle aspirate: a case report. BMC Infect Dis 16: 248.

5. Dóczi I, Bereczki L, Gyetvai T, Fejes I, Skribek Á, et al. (2015) Description of five Dirofilariasis cases in South Hungary and review epidemiology of this disease for the country. Wien Klin Wochenschr 127(17-18): 696-702.
6. Petrocheilou V, Theodorakis M, Williams J, Prifti H, Georgilis K, et al. (1998) Microfilaremia from a Dirofilaria-like parasite in Greece. Case report. APMIS. 106(2): 315-318.

7. Korkhov AP, Temirov NE, Nagornyı̆ SA, Ermakova LA, Dumbadze OS, et al. (2009) A case of the rare intraocular site of Dirofilaria spp. in man. Med Parazitol (Mosk) 1: 59.

8. Sabu L, Devada K, Subramanian H (2005) Dirofilariosis in dogs and humans in Kerala. Indian J Med Res 121(5): 691-693.

9. Levine ND (1980) Nematode parasites of domestic animals and of man. In: Levine ND (ed.), (2 ${ }^{\text {nd }}$ Edn), Burgess Publishing Co, Minneapolis, Minnesota, USA.

10. Dam T, Das P (2006) The importance of Dirofilariasis in India. Internet J Parasitic Dis 1(1).

11. Raniel Y, Machamudov Z, Garzozi HJ (2006) Subconjunctival infection with Dirofilaria repens. Isr Med Assoc J 8(2): 139.

12. Permi HS, Veena S, Prasad KHL, Kumar YS, Mohan R, et al. (2011) Subcutaneous human Dirofilariasis due to Dirofilaria repens: report of two cases. J Glob Infect Dis 3(2):199-201.

13. Khurana S, Singh G, Bhatti HS, Malla N (2010) Human subcutaneous Dirofilariasis in India: A report of three cases with brief review of literature. Indian J Med Microbiol 28(4): 394-396.

14. Patel R, Singh S, Bhavsar S (2014) A rare case of subconjunctival Dirofilariasis by Dirofilaria repens in rural Gujarat. Indian J Ophthalmol 62(5): 649-651.

15. Melsom HA, Kurtzhals JA, Qvortrup K, Bargum R, Barfod TS, et al. (2011) Subconjunctival Dirofilaria repens Infestation: A Light and Scanning Electron Microscopy Study. Open Ophthalmol J 5: 21-24.

16. Smitha M, Rajendran VR, Devarajan E, Anitha PM (2008) Case report: Orbital Dirofilariasis. Indian J Radiol Imaging 18(1): 60-62.

17. Nadgir S, Tallur SS, Mangoli V, Halesh LH, Krishna BV (2001) Subconjunctival Dirofilariasis in India. Southeast Asian J Trop Med Public Health 32(2): 244-246.

\section{Your next submission with Juniper Publishers will reach you the below assets}

